\title{
Mengupas Rentalisasi Pulau
}

Gede H. Cahyana

Bandung Pos, Agustus 1999

Konon, senyum permaisuri nan cantik amat menawan. Bak untaian zamrud katulistiwa. Memukau Sang Raja, hulubalang dan rakyatnya. Sayangnya, ia hanya tersenyum sekali saja yakni saat penobatan suaminya menjadi raja. Agar tersenyum lagi, Sang Raja dibantu oleh hulubalang dan penasihatnya mencari akal. Keputusannya, bunyikan genderang perang di tengah sunyi malam. Benarlah, Sang Permaisuri tersenyum manis melihat kehebohan rakyat menyambut bunyi genderang perang. Sebaliknya, rakyat bersungut-sungut sembari masuk serambi rumahnya ketika menyadari genderang itu hanya untuk memuaskan keinginan Raja, hulubalang dan penasihatnya.

Sekian bulan kemudian, ketika benar ada serbuan musuh dari delapan penjuru angin, genderang perang pun ditabuh bertalu-talu. Istana dikepung. Namun telah terlambat. Tak ada rakyat yang bangun karena pertahanan berbasis massa telah sirna. "Pasti Raja ingin melihat senyum manis permaisuri lagi," bisik para suami kepada istrinya sambil menggeliat di atas dipan. Dan kata sahibul hikayat, kerajaan itu - esoknya - telah dikuasai musuh. Pedihnya, musuh itu ternyata kalangan yang berkedok membantu dana pembangunan istana. Rupanya, telah lama dan dengan sabar mereka mengintai aktivitas istana dari rumah-rumah sewaan kecil di sekitarnya.

\section{Rentalisasi pulau}

Telah santer niat pemerintah menyewakan pulau-pulau kecil di nusantara. Meskipun definisi "kecil", termasuk luas dan potensinya, belum diungkap dengan jelas. Yang mengagetkan adalah substansi liputan koran ini (15/5) di bawah judul "Penyewaan Pulau Buka Lapangan Kerja". Dengan jumlah, konon 13.677 pulau atau 17.000-an pulau menurut pendapat lain - entah berapa jumlahnya yang tepat - tersirat keinginan pemerintah untuk menarik investor asing dan seperti kehabisan akal melawan degradasi ekonomi. Sementara itu, IMF makin membulan-bulani pemerintah dan merajakan dirinya di Indonesia selama tiga dekade terakhir. Tragis memang. Sebuah negara adidaya secara geografis, demografis dan sumber daya alam bernasib seperti ayam mati di lumbung padi sehingga berniat merentalisasi gugusan pulaunya.

Tak dipungkiri, rentalisasi pulau ada sisi baiknya. Penghasil devisa dan lapangan kerja adalah diantaranya. Namun hendaklah dikaji banding dengan potensi buruk yang mungkin muncul. Pernyataan yang menganggap mubazir gugusan nusa kecil itu, sesungguhnya kurang tepat karena menyewakannya justru akan memubazirkan dimensi ekologinya pada masa depan. Kendati peruntukannya hanya untuk empat macam kegiatan yakni sebagai lahan konservasi, budidaya laut, wisata dan perikanan tangkap, namun pengalaman membuktikan. Selama ini, idealisasi hanya ada pada tataran formal. Implementasinya jauh panggang dari api. Secara teoretis, pembatasan 
$40 \%$ luas pulau yang boleh dibangun dan sisanya untuk kawasan lindung, memang memungkinkan. Namun siapa yang menggaransi? Pembabatan hutan di pulau-pulau besar saja sulit dicegah meskipun diawasi dengan ketat. Hasilnya, laju deforestasi hutan kita mencapai 1,5 juta ha/tahun (skala mondial 17 juta ha per tahun untuk dekade terakhir). Dan disinyalir, tak sampai habis paruh pertama abad ke-21 nanti, hutan pun lenyap dari bumi nusantara, menambah "dosa-dosa" ekologi kita.

Rentalisasi pulau juga berisiko dari sisi politis, pertahanan dan keamanan. Atau bahasa lugasnya, penjajahan. Karena memberikan koridor kepada kolonialisme secara geografis dan politis! Tiga aspek signifikan di atas mempengaruhi "ijab kabul" sewa-menyewa yang melibatkan institusi kenegaraan bilateral. Ketergesagesaan ketika perangkat hukum dan nota kesepahaman belum jelas, dapat menjadi preseden. Dan taruhannya adalah harga diri sebagai negara berdaulat karena sekarang, ketika belum ada penyewaan pulau, spionase melintas jelas di depan mata. Kasus intersepsi pesawat mata-mata Australia oleh TNI AU, hanyalah satu contoh yang terdeteksi dan diungkap luas ke publik. Bagaimana dengan yang tidak kentara? Termasuk di sini, aktivitas para imigran gelap (kasus imigran Irak) atau para agen rahasia lainnya. Aksesnya tambah leluasa, meloncat antar pulau dengan mudahnya.

Juga bagaimana menjamin keamanan (kamtibmas), mencegah perampokan, pembabatan lahan konservasi dan perompakan laut. Gerombolan perompak makin leluasa berkelit di antara pulau dan pencuri ikan menghilang di antara seliweran kapal. Saat ini, berapa banyak pencuri ikan yang menggunakan pukat harimau (trawl) di perairan Selat Malaka dan Laut Cina Selatan, lolos begitu saja. Bahkan mereka merambah Laut Jawa, kawasan laut Sulawesi dan Nusa Tenggara Barat Timur. Mungkin kasus yang lebih parah terjadi di Kep. Maluku. Mampukah polisi perairan dan angkatan laut melakukan pengawasan melekat? Terlebih jika kalangan pabean, keamanan dan petugas terkait teledor atau mampu disusupi isu KKN. Jadi takkan ada sabuk keamanan (security belt).

Kebijakan ini pun akan membangkitkan pencurian harta karun seperti keramik, arca dan material dari kapal kandas ratusan tahun silam. Siapa penjamin bahwa tidak ada kegiatan ilegal? Karena di pulau besar yang ramai saja kegiatan ilegal dan asusila sangat marak. Logikanya, di pulau kecil terpencil tentu lebih wah karena lebih bebas, lepas dari pantauan polisi dan masyarakat. Ajang judi dan prostitusi di Pulau Batam khususnya kawasan Nagoya dan Batu Ampar, telah menjadi rahasia umum. Di Nusa Dua (Provinsi Bali) kini, secara de facto seolah-olah bukan milik warga Bali lagi karena terlalu banyak bule. Termasuk risiko kerusakan ekologi darat dan pesisir di P. Menjangan - pulau kecil di penjuru Barat Laut Pulau Bali.

Berikutnya, kerusakan budaya plus warga setempat menjadi keniscayaan akibat dari belum tercerahkan. Di kota saja, tak terhitung jumlah kaum terdidik apik yang mengadopsi mentah-mentah budaya asing tanpa memilah dan memilih secara selektif. Apatah lagi suku asli yang masih miskin ilmu itu. Imbas budaya asing yang 
represif dan akulturasi yang amat kuat, bertentangan dengan tradisinya. Selain itu, warga asli hanya akan menjadi buruh majikan asingnya. Membangun ironi di tanah leluhur. Sepatutnya, mereka diberi ruang hidup merdeka. Tidak dieksploitasi keterasingannya, dipinggirkan dan dijadikan komoditas wisata belaka. Akan tiba waktunya, budaya asing menjelma jadi racun lewat perubahan gaya hidup. Warga mengalami gegar budaya (cultural shock) sehingga tak ada cultural belt ataupun cagar budaya seperti yang diharapkan.

Lebih buruk lagi, jika dihubungkan dengan UU No. 22/1999 tentang Pemerintahan Daerah (otonomi daerah). Bukan tidak mungkin konflik terjadi antara dua atau lebih kabupaten akibat rebutan pulau. Contohnya, Kep. Seribu mau dimasukkan kemana? Apa ke salah satu kabupaten di Provinsi Jabar, Lampung atau ke Kota Jakarta Utara? Dan daerah yang punya pulau kecil akan berusaha "menjualnya" kepada asing dengan selektivitas rendah demi pendapatan asli daerah dan demi pembangunan daerah. Kemudian, muncullah "raja-raja" kecil di setiap pulau rental itu dan jumlahnya mencapai ribuan. Malah saatnya kelak, rental pulau bergeser menjadi Hak Milik Pulau seperti yang disinyalir terjadi di Kep. Seribu. Dan tentu menyulitkan pemantauan aktivitas "Sang Raja" di pulaunya. Salah-salah, justru kita yang dituduh memata-matai mereka.

\section{Kontra agenda ekologi}

Rentalisasi pulau, sedikit banyak kontra dengan agenda ekologi yang disematkan Presiden Abdurrahman Wahid yaitu peduli terumbu karang (coral reefs). Pogram yang diakronimkan menjadi SeKarang (selamatkan terumbu karang) itu pun dinilai masih parsial karena ada diferensiasi kebijakan wilayah pesisir. Belum terpadu dengan kebijakan hutan bakau (lebih tepat: hutan mangrove) yang notabene flora pantai, tetangga terumbu karang. Jika ada SeKarang hendaknya sematkan pula SeMBakau (Selamatkan Mangrove/Bakau) sehingga membantu melanggengkan ekologi di gugusan nusa kecil tersebut.

Niat merentalkan pulau telah menyajikan kebijakan tumpang tindih kendati masih dalam ranah wacana. Pasalnya, gugusan nusa yang ingin direntalkan itu justru dikitari oleh terumbu karang dan mangrove yang cenderung didegradasi. Kondisinya parah, saat ini ketika belum ada rental pulau secara de jure. Apatah lagi jika rental telah diberlakukan. Tentu pemusnahan hutan bakau (the coastal green belt) semakin sistematis. Dulu, luasnya di Indonesia 4,25 juta ha. Namun kini, taksiran optimisnya hanya 3 juta ha sedangkan pesimisnya 2,5 juta ha. Inilah dampak dari serbuan komersial, pertambangan, tambak, pertanian dan pemukiman yang tak ramah laingkungan.

Celakanya, kerusakan bakau berefek domino. Berantai! Jika bakau rusak maka fotosintesis yang memanfaatkan gas karbondioksida di pesisir berkurang. Selain meningkatkan pemanasan global (global warming) juga memperbesar kelarutannya di air laut. Lembaga lingkungan Jepang NIRE (National Institute for Resources and 
Environment) berhipotesis, 50\% CO2 dari kegiatan manusia (antropogenik) dijerap (absorbsi) oleh laut. Dan ini yang menggerus karang sehingga memperparah kerusakannya. Terlebih, proyeksi kadar CO2 tahun 2065 adalah duakali dari kadarnya pada era pra-industri (tahun 1800).

Menurut Joan Kleypas dkk (Science Vol. 284, April 1999) tingkat penurunan kalsifikasi (pengapuran) sampai tahun 2100 adalah 35\% dan berdampak pada penurunan potensi tumbuh karang (Reef-Building Capacity) sehingga karang menjadi getas (fragile coral skeleton). Terjadi reduksi pertumbuhan dan peningkatan laju erosi yang bermuara pada kehancuran terumbu karang. Ini pun diakui oleh Menteri Sarwono, yang menyebutkan hanya ada tujuh hingga sepuluh persen saja kondisi terumbu karang yang tergolong sangat baik dari total luas $60.000 \mathrm{~km} 2$. "Jumlah kerugian akibat kerusakan tersebut," demikian Menteri Eksplorasi Laut dan Perikanan, "sampai 1,2 juta dollar Amerika per tahun." Atau mari bercermin pada tenggelamnya Pulau Air Kecil, Ubi Besar, Ubi Kecil dan Vader Smith di Kep. Seribu akibat pengambilan terumbu karang.

Lebih jauh, kebijakan kontra ekologi tersebut melawan Teori Biografi Pulau (Theory of Island Biography), hasil sintesis MacArthur dan Wilson (1967). Akan muncul pergeseran kesetimbangan pulau - terlebih pulau kecil - dan rentetan dampaknya bukan saja sekarang namun ke depan khususnya bidang kesehatan, farmasi dan laboratorium aneka riset yang tak ternilai harganya. Termasuk punahnya biomaterial - yang dihebohkan saat ini - sehingga kita seperti kebakaran jenggot, tercolong di siang bolong. Apalagi jika ditimbang dengan devisa yang diperoleh sekejap ini. Sungguh tak sebanding.

Isu (tema wacana) ini pun memiriskan hati jika dikaitkan dengan polusi limbah beracun dan berbahaya. Telah banyak kasus jual beli limbah atau bahan urugan yang terkontamisasi B3 (bahan berbahaya beracun) di pulau kawasan Selat Malaka. Bahkan Singapura terang-terangan mengekspor limbah ini ke P. Batam dan sekitarnya. Maukah kita hidup di "kubangan" senyawa toksik dan radioaktif yang dibenamkan di pulau - pulau kecil itu? Maukah kita menyulut bom waktu bencana lingkungan yang saatnya kelak meledak? Karena, sebagus apapun peraturannya seperti pengalaman saat ini - fakta membuktikan, itu hanya di atas kertas. Sulit mempercayainya, apalagi jika mereka adalah warga asing yang patriotismenya terhadap negara kita dipertanyakan. Daripada menyimpan limbah beracun di negaranya, lebih murah dan aman bagi mereka dengan menjualnya atau mengirimkannya (tentu secara diam-diam) ke pulau-pulau kecil di nusantara.

Selain itu, "perkosaan" pulau makin gencar dan lancar dengan tameng studi AMDAL. Namun tradisi AMDAL (Analisis Mengenai Dampak Lingkungan) tersebut sering nyata tapi semu (virtual reality), fiktif dan mengedepankan profit and power sharing belaka. Banyak perilaku konsultan AMDAL yang laporannya hanya mengganti nama kota dan judulnya saja. Isinya sama dan sebangun dengan laporan 
lain yang telah dikerjakan sebelumnya. Anehnya, pemerintah (pusat dan daerah) okeoke saja dan tahu sama tahu. Amat mengenaskan, memang!

\section{Fokuskan ke laut}

Pulau tak dapat dipisahkan dengan laut karena "kaki" pulau adalah alas laut. Daripada rentalisasi pulau, lebih aman meningkatkan eksplorasi dan eksploitasi harta karun di laut. Potensi ekologisnya yang besar dan bernilai ekonomis, belum banyak disingkap atau hanya sebatas tataran formal, bahan diskusi saja. Akibatnya, pembangunan kelautan masih berjalan parsial sehingga hasilnya tidak optimal. Padahal ada lembaga dan jurusan di perguruan tinggi yang subjeknya bidang kelautan. Lalu, kemana arah kebijakan, teknologi dan mutu SDM yang hendak memberdayaan ekonomi rakyat khususnya nelayan, kaum pesisir yang "terpinggirkan"? Dan kapan kita mampu meraih kejayaan laut zaman Majapahit, Sriwijaya dan Samudra Pasai? Jalesveva Jayamahe?

Jika dirinci, sangat banyak sektor yang dapat didevisakan dari laut. Mulai dari perikanan, transportasi dan wisata bahari hingga ke pertambangan, "pertanian", farmasi dan energi (biomassa, angin dan gelombang). Tim riset Gordon McKerron dari Sussex University, seperti ditulis New Scientist, May 1998 menyatakan bahwa perbandingan harga (the price of power) energi gelombang terhadap energi gas, angin, batubara dan nuklir adalah 2,6 : 2,5 : 3,0 : 4,0 : 4,5 pence/kWh. Jadi, energi gelombang adalah potensi energi masa depan sebagai energi terbarui (renewable energy) yang takkan pernah habis dan relatif murah.

Dengan demikian, geliat ekonomi, untuk saat sekarang sebaiknya tetap di pulau besar. Berbarengan dengan itu, nilai kembali niat merentalkan pulau-pulau kecil sebagai ujud kecintaan kepada tanah air. Biarlah gugusan nusa itu menjadi aset masa depan ketika populasi warga kita telah melimpah sehingga harus mengisi gugusan tersebut. Sebagian kalangan berharap agar pemerintah pusat mau mendengar, melihat dan menjawab argumentasi dan opsi yang ditawarkan masyarakat. Restrukturisasi ekonomi didukung oleh devisa ramah lingkungan yang diperoleh lewat sabuk ekonomi (economic belt) namun tidak mengorbankan sabuk ekologi. Terlebih sabuk hankam, politik dan budaya. Sekaligus memasyarakatkan berfikir ekologisentris bukan ekonosentris semata. Dan akhirnya, semoga kisah rekaan yang mengawali artikel ini, tidak mewujud di sini. 